\title{
CORRIGENDUM
}

Genes \& Development 31: 1933-1938 (2017)

\section{Corrigendum: Genetic interrogation of replicative senescence uncovers a dual role for USP28 in coordinating the $\mathrm{p} 53$ and GATA4 branches of the senescence program}

Anna E. Mazzucco, Agata Smogorzewska, Chanhee Kang, Ji Luo, Michael R. Schlabach, Qikai Xu, Rupesh Patel, and Stephen J. Elledge

In the Supplemental Figures originally published for the above-mentioned article, Supplemental Figure 4 was inadvertently replaced with a second copy of Supplemental Figure 2. We have now rectified that error with the correct Supplemental Figure 4 in its proper place.

doi: $10.1101 / \operatorname{gad} .309864 .117$ 


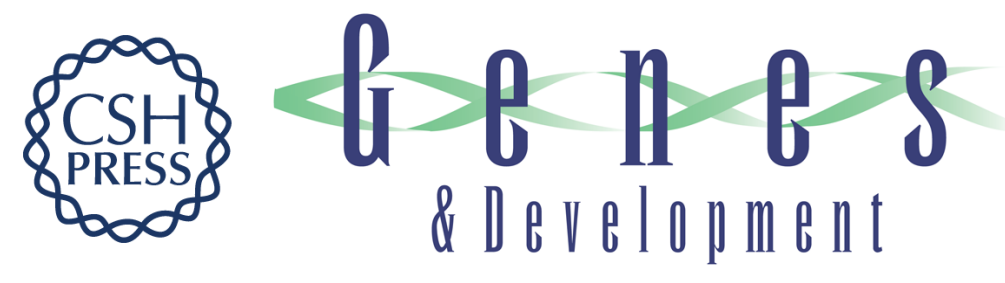

\section{Corrigendum: Genetic interrogation of replicative senescence uncovers a dual role for USP28 in coordinating the p53 and GATA4 branches of the senescence program}

Anna E. Mazzucco, Agata Smogorzewska, Chanhee Kang, et al.

Genes Dev. 2017, 31:

Access the most recent version at doi:10.1101/gad.309864.117

Related Content Genetic interrogation of replicative senescence uncovers a dual role for USP28 in coordinating the p53 and GATA4 branches of the senescence program Anna E. Mazzucco, Agata Smogorzewska, Chanhee Kang, et al.

Genes Dev. October , 2017 31: 1933-1938

License

Email Alerting Receive free email alerts when new articles cite this article - sign up in the box at the top Service right corner of the article or click here.

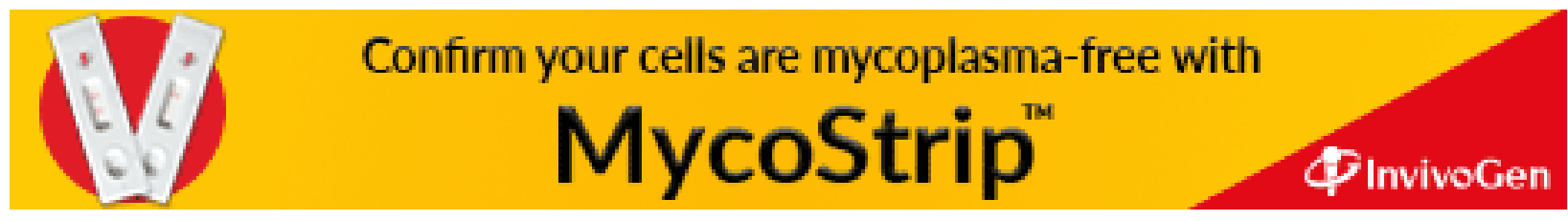

